\title{
THE LEGAL FORCE OF ELECTRONIC SIGNATURES IN ONLINE MORTGAGE REGISTRATION
}

\author{
Zainuddin, Rahmat Ramadhani \\ Faculty of Law, Muhammadiyah University of North Sumatera \\ Corresponding email: rahmatramadhani@umsu.ac.id \\ Paper received on: 13-04-2021; Revised on: 19-05-2021; Approved to be published on: 04-05-2021 \\ DOI:http://dx.doi.org/10.30641/dejure.2021.V21.243-252
}

\begin{abstract}
The legal force of electronic signatures in online mortgage registration activities is an important subject to study. Because basically the legal problems of electronic mortgage registration are also related to the validity of electronic signatures of persons who are not present before an LDO. Another issue that is important to study regarding the electronic signature in question is regarding the time limit of 7 (seven) days to register the Deed of Grant of Mortgage to the Land Registry Office. If it exceeds that time limit, the deed in question becomes null and void and it also causes sanctions against LDO. The research method used is normative juridical legal research that focused on two problems, namely; How is the legal force of electronic signatures in online mortgage registration? What are the legal problems of online mortgage registration? The results of the research showed that the Regulation of the Minister of Agrarian and Spatial Planning/the Head of National Land Agency Number 9 Year 2019 concerning Electronically Integrated Mortgage Services substantially has a tendency to contradict some of the regulations above it. Therefore, there is no detailed data protection relating to the securities registered in the electronic mortgage registration. Ignoring the time limit of 7 (seven) days will also result in administrative sanctions up to the dismissal of the LDO who neglect their duties.
\end{abstract}

Keywords: signature; electronic; mortgage

\section{INTRODUCTION}

The development of technology has an impact on the rapid growth of innovation to facilitate the activities in human life. Part of the impact of innovation in the form of electronization has made today's legal officials also have to adapt, while those who are not familiar with technology will choose to continue using the strategy that has been carried out so far (manually). The idea of an electronic deed as a result of modern inconsistencies will reduce the quality of a deed that has validity.

The use of information technology is an effort to accelerate the improvement of welfare and to facilitate people to work or receive special public services. Moreover, the development of hardware and software technology in computers has made them a valuable aid to humans in carrying out their various jobs by computerized methods.

Digital mechanisms have penetrated into the realm of public services. Information technology is indispensable in accelerating the provision of services for the people of Indonesia, an archipelago with an area that stretches from Sabang to Merauke. Especially, in land registration that requires high accuracy, the use of information technology is very relevant in accelerating the accurate land registration process ${ }^{1}$.

The Electronic Mortgage System has been in effect since the issuance of the Regulation of the Minister of Agrarian and Spatial Planning/ the Head of National Land Agency Number 9 Year 2019 concerning Electronically Integrated Mortgage Services (Permen Agraria 9/2019). Since then, the term Electronic Mortgage System which contains procedures for online mortgage registration has been known.

According to the regulation of Article 5 Paragraph (4) of the Electronic Information and Transactions Law (ITE), electronic deeds do not have the quality of confirmation that leads to correct deeds. Until recently, electronic deeds are considered as private deeds equated with electronic reports, letters and certificates. However, an agreement remains the most important part of an engagement apart from other sources as the basis for a mortgage.

There is a problem in the electronic mortgage registration procedure, that is the validity of electronic signature in the electronic mortgage

\footnotetext{
Darwin Ginting, "Land Registration In Information Technology Perspective A Basis Of Basic Agrarian Law In Indonesia," International Journal of Scientific $\mathcal{E}$ Technology Research 5, no. 5 (2016): 184-186.
} 
registration that is not signed directly in front of an LDO. Then, the existence of time limit of 7 (seven) days also has various implications when the registration exceeds the regulated time limit. In addition, from the perspective of the hierarchy of laws and regulations, the legal basis for electronic mortgage registration which is accommodated by ministerial regulations needs to be studied as to what its legal force is and whether it is contrary to the regulations above it.

Departing from the problems above, the researchers were interested in studying and analyzing the Legal Problems of Electronic Mortgage Registration, which focused on two problems, namely; How is the legal force of electronic signatures in online mortgage registration? What are the legal problems of online mortgage registration?

This research aimed to find out the legal aspect of electronic mortgage registration and various legal problems that arise from electronic mortgage registration.

Affan Muhhamad Andalan in his previous research entitled The Position of Electronic Signatures in Financial Technology Transactions has discussed how the legal position of the existence of an electronic signature is. The difference between this research and the previous research is that previous research only discussed the legal force of electronic signatures in general, meanwhile this research focuses on analyzing the legal force of electronic signatures at the time of online mortgage registration which will be directly related to its validity. Therefore, this research will become novelty in the legal literature.

\section{RESEARCH METHOD}

This study used a normative juridical research method. According to the type and nature of the research, the data sources used are secondary data consisting of primary legal materials and secondary legal materials consisting of books, scientific journals, papers and scientific articles that can provide explanations of the primary legal materials.

The analysis of the legal materials was carried out using qualitative analysis method which was used to explain legal events, legal materials or legal products in detail in order to facilitate legal interpretation ${ }^{2}$.

\section{DISCUSSION AND ANALYSIS}

\section{A. Legal Force of Electronic Signatures in Online Mortgage Registration}

The law is the basis for various implementations, one of which is for orderly administration and legal certainty of the status of mortgages that have been regulated in positive law in Indonesia. Because Indonesia, which adheres to positivism, must be based on applicable law, for example, the implementation of mortgage registration which used to be done manually is now carried out digitally.

According to the provision of Article 5 Paragraph (3) of the Electronic Information and TransactionsLaw,ElectronicDataand/orElectronic Archives must be announced substantially if there is an opportunity to use the Electronic Framework in agreement with the regulations in the Electronic Information and Transactions Law. This way, the use of Electronic Documents as evidence is considered substantial when using the Electronic Framework in agreement with the regulations regulated in Article 6 of the Electronic Information and Transactions Law, which determines that electronic archives are considered substantial as long as the data contained in them can be obtained, displayed, confirmed intaglio, and accountable, so as to clarify the situation. Control over rights contract can be seen in Law Number 4 Year 1996 concerning Mortgage.

Land registration, despite having many interpretations, should aim the same, namely the issuance of certificates of land ownership rights $^{3}$. AP Parlindungan states that delays in the registration of mortgages also provide an opportunity for third parties to object to and ask the court to demand confiscation of the object of the mortgage. As a result, the mortgage registration process cannot continue and it is very detrimental to the mortgage creditor owner who has provided a loan based on credit approval to the debtor.

\footnotetext{
Rahmat Ramadhani, "Eksistensi Hak Komunal Masyarakat Hukum Adat Dalam Pengadaan Tanah Untuk Kepentingan Umum (Indigenous Legal Communal Rights in the Land Acquisition for Public Purposes)," Jurnal Penelitian Hukum DEJURE 19, no. 1 (2019): 97-108.

3 Rahmat Ramadhani, "Korelasi Hukum Antara Pengaturan Zonasi Wilayah Dengan Pendaftaran Hak Milik Atas Tanah Di Kota Medan," Jurnal EduTech 4, no. 2 (2018): 40-49.
} 
The types of land rights that can be encumbered with mortgage consist of freehold, right to cultivate, building rights on land, rights of use on state land which according to the applicable regulations must be registered and according to their nature can be transferred, rights to land and buildings, plants and works that have existed or will exist which are an integral part of the land, and which belong to the holder of the land rights whose encumbrance is clear and expressly stated in the deed of grant of rights to the land concerned.

When it is carried out with a non-electronic process, before making a Deed of Grant of Mortgage, according to the provision of Article 39 of the Government Regulation Number 24 Year 1997 in conjunction with Article 97 of Regulation of the Minister of Agrarian Affairs/the Head of the National Land Agency Number 3 Year 1997, LDO is obliged to check the certificate to the local National Land Agency office by bringing the original certificate. There are 3 (three) possible results from the examination.

First, if the certificate is in accordance with the existing register, the Head of the Office is appointed to sign the page of change of the original certificate or write the sentence: "has been checked and is in accordance with the register", then the examination is initialized.

The legal protection expected by banks as preferred creditors will certainly not stop with credit agreement and binding guarantees, because there are things that need to be done, which are a continuation of the legal actions that have been taken above. Enforcement of loan rights from Deed of Grant of Mortgage made by an LDO must be followed by registration at a land registry office. No later than 7 (seven) working days after the signing of the Deed of Grant of Mortgage, the LDO is required to send relevant evidences and other necessary documents.

Ownership rights are born on the date of the land book 7 days after the files are completed. It is known as the publicity principle (Article 13 of Mortgage Law). Regarding credit rights in accordance with the Mortgage Law, it is a process consisting of two stages, namely granting and registration.

The creditor holding the mortgage has the right to precede the other creditors (droit de preference) to take repayment from the sale of the collateral for the land. Then the Mortgage also continues to encumber the Mortgage object in the hands of whoever the object is. This means that the Creditor holding the Mortgage still has the right to auction the object, even though the rights have been transferred to another party (droit de suite) ${ }^{4}$.

Second, if the certificate is not issued, the cover and all pages of the certificate shall be stamped or given the sentence: "this certificate is not issued...". Third, if it turns out that the certificate is issued by the Land Registry Office, but the physical data contained therein is no longer for the people recorded in the book and the survey certificate, then the relevant certificate is from LDO from the Land Registration which is related to the data recorded separately. There is no mark on the certificate. The LDO must refuse the issuance of the Deed of Grant of Mortgage, if it turns out that the certificate submitted to him is not a document issued by the Land Registry Office or the data contained therein no longer matches the registry at the National Land Agency.

After checking the certificate, the LDO will see if the right holder has the right to take legal action, whether it is performed for themselves or acting based on the husband/wife agreement to guarantee the ownership rights together. Especially for children under 21 years old, before the making of the Deed of Grant of Mortgage, it must be resolved by the determination of the local District Court ${ }^{5}$. Basically, a mortgage is a guarantee right for debt repayment ${ }^{6}$. Mortgage shall be given after there is principal agreement in the form of a loan agreement ${ }^{7}$.

Article 10 Paragraph (2) of Mortgage Law confirms that the Granting of Mortgage shall be carried out by signing the Deed of Granting of Mortgage by an LDO which must be in accordance with the provisions of the applicable laws and regulations and the enactment of a Mortgage has been regulated in Article 13 Paragraph (1) of Mortgage Law, namely the granting of mortgages

4 Rahmat Ramadhani, Buku Ajar Hukum Agraria (Suatu Pengantar), (Medan: CV. Pustaka Prima, 2018), 111.

5 Wiwin Yulianingsih and Dea Syagita Noviana, "Perlindungan Hukum Bagi Bank Sebagai Kreditur Pemegang Hak Tanggungan Berobyek Hak Guna Bangunan (HGB)," Perspektif Hukum 12, no. 2 (2012): 1.

6 Rahmat Ramadhani, Dasar-Dasar Hukum Agraria (Medan: CV. Pustaka Prima, 2019), 125.

7 Kartini Muljadi and Gunawan Widjaja, Hak Tanggungan, Seri Hukum Harta Kekayaan (Jakarta: Kencana, 2006), 213. 
must be registered with the land registry office. From the two regulations above, it is an absolute requirement for the creditor, which in this case is bank in providing credit to debtors with mortgage guarantee, to make a Deed of Granting of Mortgage as a guarantee for repayment of debtors' debts in the future where the creditor, in this case the bank, has the right to take precedence (preference) from other creditors. The date of the mortgage land book is the seventh day after the complete receipt of the documents required for the registration and if the seventh day is a holiday, the relevant land book shall be dated the next working day.

According to Article 10 Paragraph (2) of Mortgage Law, the granting of guarantee of rights shall be carried out by signing the Deed of Granting Guarantee of Rights by LDO which must be in accordance with the provisions of applicable laws and regulations and for the enactment of mortgage rights, the provisions that have been regulated In Article 13 Paragraph (1) of the Mortgage Law, the granting of mortgage rights must be registered with the land registry office. According to the two regulations above, it is absolute requirement for creditors, in this case the bank, in providing credit for debtors with guaranteed mortgage, to make a Deed of Grant of Mortgage as a guarantee for repayment of debtors' debts in the future where the bank has the right credit rights (preferred) from other creditors. The date of title of land for mortgage is the seventh day after complete receipt of documents required for registration.

Then the mortgage certificate is taken and kept by the bank as collateral for the debtor's loan. However, if the Deed of Grant of Mortgage registration faces a delay which actually must be registered with the land registry office 7 (seven) days since the Deed of Grant of Mortgage is signed by both parties, then the LDO is required to make a statement concerning the delay with the reasons.

In practice, so far, the registration of the Deed of Grant of Mortgage through LDO has been implemented in accordance with the applicable regulations. However, there are also LDOs who registered Deed of Grant of Mortgage beyond the specified time limit. The provisions of the registration can be found in Article 13 Paragraph (2) of Mortgage Law which states that: on the last 7 (seven) working days after the signing of the Deed of Grant of Mortgage (2), the LDO must send the Deed of Grant of Mortgage and other documents to the Land Registry Office. The Government Regulation Number 24 Year 1997 states that: on the $7^{\text {th }}$ (seventh) working days the LDO must submit the deed along with the relevant documents for registration. "The registration of mortgage is intended to ensure that the mortgage certificate exists and that the creditor as a party protected by law is the creditor who takes precedence.

In summary, Articles 13-14 of Mortgage Law regulate the registration of mortgage. At the initial stage, the registration is carried out at the Land Registry Office. The Land Deed Official (LDO), within 7 days after the signing of the grant of Mortgage, is required to submit the Deed of Grant of Mortgage (APHT) and other documents to the Land Registry Office and bring files in the form of: Introduction letter from the LDO made in two copies and contains a list of types of letters sent; Application letter for registration of Mortgage of the Beneficiary; A copy of the identity letter of the giver and the holder of the Mortgage; Certification of original land rights or freehold of an apartment that is the object of Mortgage; The second sheet of the Deed of Grant of Mortgage; a copy of the Deed of Grant of Mortgage that has been given initial by the relevant LDO to be certified as a copy by the Head of the Land Registry Office for the making of a Mortgage Certificate.

As a proof of payment of the mortgage registration fee, the owner will make a lien book and record it in the book of rights of land which is the object of the mortgage and copy the notes to the relevant Land Rights Certificate. The date of the land book is the seventh day after receipt of complete documents required for registration. If the seventh day falls on a holiday, the books shall be given on the next working day.

Currently, after the issuance of the Regulation of the Minister of Agrarian and Spatial Planning No. 9/2019, the procedure for registering mortgage that are registered electronically, basically, users must be registered with the provision that the Electronic mortgage system consists of individuals/legal entities as creditors and State Civil Apparatus who is responsible for mortgages, matters previously referred to as legal users who are registered as users of the mortgage system, registered with electronic authorities: statements of fulfilment of the requirements and criteria and approval of the conditions as registered users; and other conditions stipulated by the Ministry. The 
Ministry verifies its registration and reserves the right to refuse its registration ${ }^{8}$.

Ashiddiqie, in Hadita (2018), states that referring to Hans Kelsen's theory of the norm level and Hans Nowiasky's theory of legal norms, we can see the reflection of these two norm systems in the Indonesian legal system (type of Indonesian hierarchy). One legal requirement that is applied, sourced, and based on higher legal norms above, and higher legal norms also always refer to higher legal norms. The principle of the statute is that a lesser statute should not conflict with a higher statute. Article 26 of the Electronic Information and Transactions Law essentially stipulates that personal data registered online needs to be guaranteed, in this context, the personal data of the mortgage holder to the legal force and security of trace of the digital signature that is registered when registering mortgages online ${ }^{9}$.

The electronic mortgage system as referred to in Article 1 Number 6 of the Regulation of the Minister of Agrarian and Spatial Planning is essentially a systematization of the mortgage service process in the context of maintaining land registration data held through an integrated electronic system. The implementation of the electronic mortgage system is carried out by the land registry office gradually to adjust to the readiness of the supporting data. One type of mortgage service that can be delivered through the electronic mortgage system is the registration of mortgage. In addition, this system also serves the transfer of mortgage, changes in the name of creditors and the abolition of mortgage.

Article 2 Paragraph (1) of the Regulation of the Minister of Agrarian and Spatial Planning/the Head of the National Land Agency Number 3 Year 2019 concerning the Application of Electronic Signatures (Permen Agraria 3/2019) explains that electronic signatures can be used to approve and/ or declare land documents in the implementation of the duties and functions of the Ministry of Agrarian and Spatial Planning.

8 Bernadetha Aurelia Oktavira, "Mekanisme Pendaftaran Hak Tanggungan Secara Elektronik," last modified 2020, accesed Juli 20, 2020, www.hukumonline.com.

9 Cynthia Hadita, "Registrasi Data Pribadi Melalui Kartu Prabayar Dalam Perspektif Hak Asasi Manusia (Provision of Personal Information in Prepaid SIM Card Registration from Human Rights Perspective)," Jurnal HAM 9, no. 2 (2018): 191-204.
The thing that needs to be underlined is that electronic signatures can only be made after the signers have an electronic certificate. To obtain this electronic certificate, the official submits an application for registration of the electronic signature to the registration authority of the working unit in the Ministry.

The problem in the electronic mortgage registration process is related to the signature of the head of the National Land Agency, a copy of the deed pursuant to the original to show its authenticity, the validity of the LDO's electronic initial, and the limit of 7 (seven) days of completeness of all documents. Then the legal force, which is only limited to ministerial regulations. There are also no further regulations relating to legal protection for various documents that are inputted, especially object certificates which are the original mortgage. This is because this matter is contrary to the Mortgage Law which stipulates that LDO is obliged to check by bringing the original documents to the land registry office.

\section{B. Legal Problems of Online Mortgage Registration}

Basically, the Mortgage Law intends to provide legal certainty and protection for the parties (debtors and creditors) of rights of land that is used as collateral. Moreover, along with the increase of the population to date, it demands a person to have plot of land for living and working for his life ${ }^{10}$.

In an effort to provide legal certainty for land and its boundaries, Article 19 of the Basic Agrarian Law authorizes the government to register land and to make peace. Meanwhile, private public participation, called sporadic registration, is also expected in land registration, given restrictions in government finances. For the first time, land registration including land survey, mapping, and recording, registration of land titles, and issuance of land certificates is relatively expensive. Systematically, there are several problems in land registration, including:

1. Minimum handling of land issues. Frequent cases of double certificates because registered packages are not included in the registration

\footnotetext{
1o Ahyar Ari Gayo, "Perlindungan Hukum Hak Atas Tanah Adat (Studi Kasus di Provinsi Aceh Khususnya Kabupaten Bener Meriah), Jurnal Penelitian Hukum Dejure, Volume 18 No. 3 (2018): 290
} 
map. Lack of large-scale maps as an important tool in land registration, Government Regulation No. 24 Year 1997 stipulates that the implementation of registration must be simple, secure, and affordable. However, its implementing regulations do not reflect the simplicity in that the procedures pursued in the registration process are protracted and expensive.

2. Many Non-integrated Regulations are components (work units) in character so that the services become protracted, expensive, and not transparent. Separation of provinces, regencies, municipalities, and villages, or subsequent mergers of villages, need efforts to regulate that SOPs are implemented by online information technology so that services are transparent, effective and efficient. The use of CORS facilitates and accelerates the realization of the administrative sequence of land affairs including land registration which consists of land survey, mapping, and recording activities at high accuracy and relatively low cost. This issue is consistent with the mandate of Decree of the People's Consultative Assembly No. IX/MPR/2001, which stipulates Agrarian and Natural Resource Management Reform.

Basically, the legal problems of land rights that occur today in Indonesia are not only limited to disputes between land rights holders and other parties. This means that the certificate of land rights that has been registered may also contain a myriad of problems, both regarding other parties (subjects of other rights) and regarding the subject of the rights holder as stated in the certificate of land rights (himself) ${ }^{11}$.

In connection with the transfer of rights due to the transfer of credit, collateral or guarantee does not have to be transferred by law to a third party or new creditor when the credit agreement is agreed because it must go through an initial repayment for the initial creditor. Payments are made so that the old mortgage is written down and released and then re-imposed with the new mortgage for the benefit of the new creditor. This is because one of the reasons for the waiver of down rights is that it can only occur when the debt secured by the down

"Rahmat Ramadhani, Beda Nama dan Jaminan Kepastian Hukum Sertifikat Hak Atas Tanah, (Medan: CV. Pustaka Prima, 2018), 10. rights has been repaid. The characteristics of loan rights based on General Elucidation Number 3 of Mortgage Law, namely: giving priority positions, always following the object guaranteed in the hands of whoever this object is, fulfilling the principles of specialization and publicity so that it can bind third parties and provide legal certainty for the parties concerned, easy and determined execution. Through two stages of activity, namely: the stage of granting mortgage rights, with the Deed of Grant of Mortgage by LDO which previously was a guaranteed Debt Agreement period and the second stage is registration by the Land Registry Office.

Land with mortgage status should have executive power for certain creditors over other creditors. However, in the implementation, there are still difficulties for banks as creditors to carry out the execution of collateral land that has been placed under Mortgage. Difficulties to run by the bank, on land that has been encumbered mortgage, will affect the sound of the bank and this is certainly not desirable by the bank management. For this reason, the researchers were interested in examining the procedures for handling land rights according to the Mortgage Law and executive credit of mortgage certificates in the process of resolving land disputes according to the Mortgage Law both in the case of debtors and banks as creditors who have encumbered mortgages on land mortgage. Khoidin states that the registration of mortgages must use the system of registration of deed, not registration of title.

The obligation to register rights is intended to guarantee legal certainty to the giver and recipient of the mortgage and to provide legal protection when one party takes an action that harms the other party. For example, when it cannot pay off the debt borrowed from the mortgage holder, then by registering the mortgage, the mortgage holder has strong legal force to receive payment from the recipient by executing the land that is encumbered with the mortgage. According to Article 13 of the Mortgage Law, the granting of mortgages must be included in full, both the subject, including the debt guaranteed by the mortgage, as well as the obligation to register the mortgage at the local office. This registration is intended as an inside announcement regarding the parties, as well as the community in general. 
The land registration system applied is the registration of deed. By registering with this system, it is intended that what is registered is an act that contains legal actions that give birth to land rights, such as land rights, including eigendom, freehold, including registration of mortgage using registration of title.

After the process of registration of mortgage has been completed, the mortgage certificate will be handed over to the credit holder/credit right holder which is also kept by the credit right holder/credit right holder, even in the practice of land certificates, records of property rights are also kept by the land owner right holder/rights of credit holders, holders of rights to return patent rights from freehold, referred to in Article 14 Paragraph (4) of Mortgage Law. The purpose of implementing a mortgage is to provide a strong guarantee for creditors who are holders of mortgages. Therefore, if the debtor does not promise, credit rights from the lower party, the right to make a sale in public (auction) or privately and take all part of the debt to pay the debt with the main priority rights (from other parties). Inaccuracies in the registration period for mortgages have various legal consequences. In practice, those who consider themselves as the recipients of credit rights/recipient of mortgage and LDO. This condition often causes tension/ disharmony in the relationship between creditors and LDO/Notaries. Inaccurate completion of mortgage registration has caused legal uncertainty for the parties and does not provide strong legal protection, especially for creditors who have provided funds for creditors. Inaccuracies in the completion of mortgage registration also result in a the society's trust in LDO/Notary. Certainty of registering credit rights is very important for creditors. At this time, it does not only determine the preferred position (droit de preferent) for creditors, but also determines their rank in relation to other creditors who also hold mortgage, with the same land as collateral. To obtain certainty regarding the time of registration, a certain period of time has been determined as follows: The delivery of the Deed of Grant of Mortgage and the mark for registration is determined no later than 7 (seven) working days after signing, the date of the land book is the seventh day after the required certificates are completed for receipt of registration and if the day is a holiday, the next working day shall be the date of the land book, the delivery of the Deed of Grant of Mortgage and the mark has been made. To comply with this provision, Article 23 Paragraph (1) stipulates administrative sanctions that can be imposed to officials who violate or neglect to apply such provision.

The legal force of a mortgage certificate is difficult to prove if the original certificate is lost. In addition, another problem arises, namely the legal protection for holders of mortgage certificates that have been lost. For the mortgage certificate holder, it will be difficult to get protection, because this has not been regulated in the Mortgage Law, causing a legal vacuum.

One of the land rights as evidenced by the ownership of the certificate by the mortgage holder, is to guarantee the land rights, the collateral can be securities, or land to the bank for the purpose of taking additional funds or certain financing, by being encumbered with mortgage.

If compensation cannot be given, then the last action for the bank is to take over the collateral that has been guaranteed by the customer in this case in the form of land and/or buildings that have been secured by mortgage. In this case, if it has gone through the judicial process of the loan agreement in the mortgage, but still cannot fulfil its obligation. If the debtor fails to pay, the first mortgage holder has the right to sell the title item at his own discretion through a public auction and receive payment from the sale of the asset, that if the first sale lien holder has claimed his rights. This concept is known as Parate execution as referred to in Article 1178 Paragraph (2) of the Civil Code.

Mortgage is charged for collateral objects that are still in the process of being converted to property rights, the validity of which is legally valid, while the administrative process has not been completed, it is possible to become collateral for debts with mortgages. The making of the principal agreement in this case is a credit agreement between the creditor and the debtor.

The provision of Article 10 Paragraph (3) of the Mortgage Law is exception to the principle that the object of the mortgage is registered and transferable land because in this provision there is a chance that the mortgage of land from the conversion of the old rights have met the requirements, but cannot be registered because according to the records, it cannot be registered. It can be seen that in the case of land rights that are used as mortgage objects, there is no land 
registration certificate, then the registration of these land rights will be carried out simultaneously with the application of mortgage.

If data protection in the electronic mortgage registration process uses sanctions in the Electronic Information and Transactions Law, there are controls that are not used in relation to evidence, especially the recognition of electronic records as evidence. Based on the provision of Article 5 Paragraph (1) of the Electronic Information and Transactions Law, it is stipulated that electronic data and/or electronic reports and/or printouts constitute substantial legal evidence. In addition, in Article 5 Paragraph (2) of the Electronic Information and Transactions Law, it is stipulated that electronic data and/or electronic reports and/or printouts as mentioned in Paragraph (1) constitute the development of legal evidence in understanding with the appropriate procedural law in Indonesia. Appropriately, the Electronic Information and Transactions Law has stipulated that electronic file and/or printouts are valid evidence and can be used recently in court proceedings.

Furthermore, an LDO who neglects his duties as regulated in Article 62 of Government Regulation Number 24 Year 1997 may be subject to administrative sanction in the form of a written warning up to dismissal from his position as an LDO as regulated in Article 23 Paragraph (1) of the Mortgage Law.

\section{CONCLUSION}

The legal force of electronic signatures in online mortgage registration refers to Article 5 Paragraph (3) of the Electronic Information and Transactions Law which states that Electronic Data and/or Electronic Archives must be announced substantially. This means that the use of Electronic Documents as evidence that is considered substantial when using the Electronic Framework in an agreement is in accordance with the formulation of Article 6 of the Electronic Information and Transactions Law, namely that electronic archives shall be considered substantial as long as the data contained therein can be obtained, displayed, confirmed intaglio, and accountable. Therefore, it can be used as control over the substance of the engagement as regulated in Law Number 4 Year 1996 concerning Mortgage.
The problem in online mortgage registration is that there is a time limit of 7 (seven) days. Even though there are administrative sanctions in the form of a written warning up to dismissal from their position as LDO who neglect their duties, these sanctions are rarely heeded. Then, various regulations regarding online mortgage registration have not regulated data protection in detail in the registration process which inputs various documents including securities. These regulations have not regulated the sanctions in the Electronic Information and Transactions Law in detail.

\section{SUGGESTION}

The regulation of electronic signatures in online mortgage registration still refers to the legal umbrella in the form of Regulation of the Minister of Agrarian and Spatial Planning/ the Head of the National Land Agency Number 3 Year 2019 concerning the Application of Electronic Signatures which has not regulated its connection with Law Number 19 Year 2016 concerning Amendments to Law Number 11 Year 2009 concerning Electronic Information and Transactions. Therefore, it is necessary to make changes to the Mortgage Law so that its hierarchical position is in line with the Electronic Information and Transactions Law. So that there is no conflict between ministerial regulations and the Mortgage Law and the electronic mortgage registration procedure, where the signature before a notary, the phrase on the deed that the copy corresponds to the original.

It is also necessary to review the Regulation of the Minister of Agrarian and Spatial Planning/ the Head of the National Land Agency Number 3 Year 2019 concerning the Application of Electronic Signatures in relation to the issue of the time limit of 7 (seven) days. Because, regarding electronic signatures and data protection, more detailed regulations are needed to minimize legal implications that may occur in the future.

\section{ACKNOWLEDGEMENT}

First and foremost, the researchers would like to convey gratitude to Allah SWT. Because of His mercy and blessing, this journal can be completed. The researchers would also like to convey salawat for the Great Prophet Muhammad SAW. Hopefully what is written in this journal 
will become a flowing and ongoing charity for His intercession later in yaumil masyar. Amen.

We would like to thank our parents, children and beloved wives, for continuously supporting the researchers in everything, especially in the world of writing.

\section{BIBLIOGRAPHY}

Gayo, Ahyar Ari, "Perlindungan Hukum Hak Atas Tanah Adat (Studi Kasus di Provinsi Aceh khususnya Kabupaten Bener Meriah), Jurnal Penelitian Hukum Dejure, Volume 18 No. 3 (2018)

Ginting, Darwin. "Land Registration In Information Technology Perspective A Basis Of Basic Agrarian Law In Indonesia.” International Journal of Scientific \& Technology Research 5, no. 5 (2016): 184-186.

Hadita, Cynthia. "Registrasi Data Pribadi Melalui Kartu Prabayar Dalam Perspektif Hak Asasi Manusia (Provision of Personal Information in Prepaid SIM Card Registration from Human Rights Perspective).” Jurnal HAM 9, no. 2 (2018): 191-204.

Muljadi, Kartini, and Gunawan Widjaja. Hak Tanggungan, Seri Hukum Harta Kekayaan. Jakarta: Kencana, 2006.

Oktavira, Bernadetha Aurelia. "Mekanisme Pendaftaran Hak Tanggungan Secara Elektronik." Last modified 2020. www. hukumonline.com.

Ramadhani, Rahmat. Beda Nama Dan Jaminan Kepastian Hukum Sertifikat Hak Atas Tanah. Medan: CV. Pustaka Prima, 2018.

—. Buku Ajar Hukum Agraria (Suatu Pengantar), Medan: CV. Pustaka Prima, 2018.

. Dasar-Dasar Hukum Agraria. Medan: CV. Pustaka Prima, 2019.

. "Eksistensi Hak Komunal Masyarakat Hukum Adat Dalam Pengadaan Tanah Untuk Kepentingan Umum (Indigenous Legal Communal Rights in the Land Acquisition for Public Purposes)." Jurnal Penelitian Hukum DE JURE 19, no. 1 (2019): 97-108.
- "Korelasi Hukum Antara Pengaturan Zonasi Wilayah Dengan Pendaftaran Hak Milik Atas Tanah Di Kota Medan.” Jurnal EduTech 4, no. 2 (2018): 40-49.

Yulianingsih, Wiwin, and Dea Syagita Noviana. "Perlindungan Hukum Bagi Bank Sebagai Kreditur Pemegang Hak Tanggungan Berobyek Hak Guna Bangunan (HGB)." Perspektif Hukum 12, no. 2 (2012): 1. 
HALAMAN KOSONG

252 Jurnal Penelitian Hukum De Jure Vol. 21 No. 2, Juni 2021: 243-252 